\title{
Universally Primed Polymerase Chain Reaction Alleles and Internal Transcribed Spacer Restriction Fragment Length Polymorphisms Distinguish Two Subgroups in Botrytis aclada Distinct from B. byssoidea
}

\author{
K. Nielsen, A. F. Justesen, D. Funck Jensen, and D. S. Yohalem
}

First, second, and fourth authors: Department of Crop Protection, Danish Institute of Agricultural Sciences, Forsoegsvej 1, 4200 Slagelse, Denmark; and third author: Department of Plant Biology, The Royal Veterinary and Agricultural University, Thorvaldsensvej 40, 1871 Frederiksberg C, Denmark.

Accepted for publication 13 February 2001.

\begin{abstract}
Nielsen, K., Justesen, A. F., Funck Jensen, D., and Yohalem, D. S. 2001. Universally primed polymerase chain reaction alleles and internal transcribed spacer restriction fragment length polymorphisms distinguish two subgroups in Botrytis aclada distinct from B. byssoidea. Phytopathology 91:527-533.

Fifty-one isolates representing the four Botrytis spp. associated with onion neck rot were clustered by unweighted pair group method with arithmetic mean based on universal-primed polymerase chain reaction (UP-PCR) fingerprints. Bootstrap analysis of the consensus phenogram clearly demonstrated five strong clusters among the four Botrytis spp.: $B$. cinerea (C), B. squamosa (S), B. byssoidea (B), and B. aclada (AI and AII). Subdivision of the $30 \mathrm{~B}$. aclada isolates, AI (14) and AII (16), from Europe,
\end{abstract}

ABSTRACT

Botrytis is a fungal form genus including 22 species (6) that causes disease on a wide range of crops and ornamentals. Onions (Allium cepa L.) are attacked by at least seven Botrytis spp. (5), and Walker (27) distinguished three that cause neck rots in onions: B. aclada Fres. (syn. B. allii Munn), causal agent of neck rot (name originally proposed by Walker [27] was gray mold neck rot); B. byssoidea Walker (teleomorph Botryotinia allii [Sawada] Yamamato), causal agent of mycelial neck rot (27); and Botrytis squamosa Walker (teleomorph Botryotinia squamosa Vien.-Bourg), causal agent of small sclerotial neck rot of white onion cultivars (27). B. squamosa is better known as the causal agent of onion leaf blight. B. cinerea Pers. Fr. (teleomorph Botryotinia fuckeliana [de Bary] Whetz.) causes leaf spots and brown staining of onion bulbs (7) and is occasionally isolated from diseased onion bulbs. Of these onion pathogens, B. aclada is most commonly associated with onion neck rot disease, where storage losses in excess of $50 \%$ have been observed (13-15).

B. aclada and B. byssoidea cause similar symptoms and their spore sizes overlap (5). This has led several researchers to postulate that $B$. byssoidea and $B$. aclada are conspecific $(7,9)$. However, Owen et al. (22) studied the variability of B. aclada and $B$. byssoidea and concluded that the two species are valid. Morphological characteristics of the conidiophore and cytological measurements of the average number of nuclei in conidia have been used to separate B. aclada and B. byssoidea $(17,26)$. However, no consensus has yet been reached on the taxonomic status of $B$. byssoidea and B. aclada.

Corresponding author: D. S. Yohalem; E-mail address: David.Yohalem@agrsci.dk

Publication no. P-2001-0328-02R

(C) 2001 The American Phytopathological Society
Egypt, North America, and Japan was further supported by restriction analysis of the internal transcribed spacer of the ribosomal genes and spore size measurements. Gene diversities $(H)$ among AI and AII isolates were very low ( 0.007 and 0.043 , respectively). A likelihood ratio chisquare test $\left(G^{2}\right)$ of Nei's coefficient of genetic differentiation $\left(G_{\mathrm{ST}}\right)$ showed that both $B$. aclada subgroups, AI and AII, were significantly different from $B$. byssoidea $(P<0.001)$, and that $B$. aclada subgroups AI and AII were significantly different from each other $(P<0.001)$. No UP-PCR alleles were shared by AI and B. byssoidea isolates, whereas 10 and 12 alleles were shared by AI:AII and AII:B. byssoidea, respectively. The hypothesis that AII may be a hybrid between AI and B. byssoidea is discussed.

Additional keywords: Botryotinia, DNA fingerprint, hybrid species.

B. aclada consists of two subgroups based on spore measurements (5), and chromosome number in the nuclei (26). Shirane et al. (26) found that cells in the mitotic phase of seven Botrytis spp. (including B. aclada, B. byssoidea, B. cinerea, and B. squamosa) all contained 16 chromosomes. However, one subgroup of the B. aclada isolates contained 32 chromosomes per nucleus and produced spores that were bigger than the $B$. aclada isolates with 16 chromosomes. Shirane et al. (26) speculate that the 32 chromosome subgroup is an autodiploid of the 16 chromosome subgroup.

We are working with development of molecular markers for detection of neck rot organisms (21), and to accomplish this it is essential that (i) inter- and intraspecific variability of Botrytis spp. pathogenic to onions, and (ii) the taxonomic status of $B$. byssoidea and $B$. aclada be addressed. We have obtained isolates from Europe, Japan, North America, and North Africa and calculated their genetic variability by universal primed polymerase chain reaction (UP-PCR), a variant of random amplified polymorphic DNA (29) with greater reproducibility due to use of longer primers and higher annealing temperature $(2,3,18)$. Objectives of this work were to study the molecular and morphological variability of Botrytis spp. associated with neck rot of onions, with particular focus on B. aclada.

\section{MATERIALS AND METHODS}

Fungal material and spore measurements. Botrytis isolates were obtained from fungal culture collections or were collected in different onion fields in Denmark (Table 1). Fungal isolates were grown on potato dextrose agar (PDA) (Difco Laboratories, Detroit) and, for long-term preservation, were stored in a $15 \%$ glycerol suspension at $-80^{\circ} \mathrm{C}$. For production of conidia, isolates were grown on onion leaf extract agar (OEA; $15 \mathrm{~g}$ of dried onion 
leaves and $16 \mathrm{~g}$ of agar per 1 liter of $\mathrm{dH}_{2} \mathrm{O}$ ) for 14 days at $21^{\circ} \mathrm{C}$ under black light. Length and width of 100 conidia from each isolate of $B$. aclada were measured at $\times 500$ magnification under Nomarski optics. Morphological verification of isolates of $B$. byssoidea and B. squamosa was difficult because these isolates did not sporulate on either PDA or OEA.
DNA extraction. For DNA extraction, fungi were grown for 5 to 7 days at room temperature in the dark on PDA covered with a dry sterilized $\left(120^{\circ} \mathrm{C}\right.$ for $\left.12 \mathrm{~h}\right)$ disc of cellophane. Mycelia were scraped from the cellophane and ground in liquid nitrogen with a mortar and pestle. Powdered mycelium $(30 \mathrm{mg})$ was transferred to an Eppendorf tube, and DNA was extracted according to the

TABLE 1. Botrytis spp. isolates used in this study

\begin{tabular}{|c|c|c|c|c|c|c|}
\hline Isolate no. & Original no. & Origin & Isolated from & Spore size $(\mu \mathrm{m})^{\mathrm{a}}$ & UP-PCR group ${ }^{b}$ & ITS $\operatorname{Sph} 1^{\mathrm{c}}$ \\
\hline \multicolumn{7}{|l|}{ B. aclada } \\
\hline BA1 & $\mathrm{BA} 1^{\mathrm{d}}$ & Denmark & Bulb of Allium cepa & $9.0 \times 5.0$ & AI & 3 \\
\hline BA2 & $\mathrm{BA} 2^{\mathrm{d}}$ & Denmark & Bulb of Allium cepa & $9.0 \times 4.8$ & AI & 3 \\
\hline BA3 & MUCL $8^{\mathrm{e}}$ & Belgium & Bulb of Allium cepa & $8.9 \times 4.6$ & AI & 3 \\
\hline BA4 & MUCL 403 & Netherlands & Bulb of Allium cepa & $9.9 \times 5.3$ & AII & 2 \\
\hline BA5 & MUCL 99 & U.S. & Bulb of Allium cepa & $10.4 \times 6.5$ & AII & 2 \\
\hline BA6 & MUCL 961 & Belgium & Bulb of Allium cepa & $10.3 \times 5.9$ & AII & 2 \\
\hline BA7 & MUCL 1150 & Norway & Bulb of Allium cepa & $10.1 \times 5.7$ & AII & 2 \\
\hline BA8 & MUCL 3037 & Canada & Bulb of Allium cepa & $9.1 \times 4.8$ & $\mathrm{AI}$ & 3 \\
\hline BA9 & MUCL 3106 & U.S. & Bulb of Allium cepa & $9.2 \times 5.2$ & $\mathrm{AI}$ & 3 \\
\hline BA10 & MUCL 3109 & Japan & Leaf of Allium cepa & $10.6 \times 5.8$ & AII & 2 \\
\hline BA11 & MUCL 3614 & Egypt & Bulb of Allium cepa & $14.1 \times 6.3$ & AII & 2 \\
\hline BA12 & MUCL 494 & Denmark & Bulb of Allium ascalonicum & $9.7 \times 5.8$ & AII & 2 \\
\hline BA13 & MUCL 8415 & Germany & Bulb of Allium cepa & ns & AI & 3 \\
\hline BA14 & MUCL 9114 & Netherlands & Leaf of Allium cepa & $\mathrm{ns}$ & AII & 2 \\
\hline BA16 & MUCL 18868 & Scotland & Bulb of Allium cepa & $13.0 \times 5.9$ & AII & 2 \\
\hline BA17 & MUCL 18967 & England & Leaf of Allium ascalonicum & $12.1 \times 5.9$ & AI & 3 \\
\hline BA18 & $\mathrm{B} 4065^{\mathrm{f}}$ & UK & Bulb of Allium cepa & $9.2 \times 5.2$ & AI & 3 \\
\hline BA19 & B $4090^{f}$ & UK & Bulb of Allium cepa & $10.4 \times 5.6$ & AI & 3 \\
\hline BA20 & $61-2^{g}$ & U.S. & Allium cepa & $10.2 \times 5.9$ & AII & 2 \\
\hline BA21 & 3-DK99d & Denmark & Bulb of Allium cepa & $9.8 \times 5.5$ & $\mathrm{AI}$ & 3 \\
\hline BA22 & 8-DK99d & Denmark & Bulb of Allium cepa & $9.6 \times 5.2$ & AI & 3 \\
\hline BA23 & $13-\mathrm{DK} 99^{\mathrm{d}}$ & Denmark & Bulb of Allium cepa & $10.1 \times 6.2$ & AII & 2 \\
\hline BA24 & MUCL 1105 & U.S. & $-{ }^{\mathrm{h}}$ & $12.2 \times 7.3$ & AII & 2 \\
\hline BA25 & MUCL 3528 & - & - & $11.4 \times 5.6$ & AII & 2 \\
\hline BA26 & MUCL 3537 & - & - & $10.7 \times 6.0$ & AII & 2 \\
\hline BA27 & MUCL 3556 & UK & Bulb of Allium cepa & $11.9 \times 5.9$ & AII & 2 \\
\hline BA28 & MUCL 3810 & Belgium & Bulb of Allium cepa & $8.4 \times 5.5$ & $\mathrm{AI}$ & 3 \\
\hline BA29 & MUCL 20329 & Belgium & Allium schoenoprasum & $9.2 \times 4.8$ & $\mathrm{AI}$ & 3 \\
\hline BA30 & CBS $260.71^{\mathrm{i}}$ & Denmark & Bulb of Allium сера & $9.2 \times 4.9$ & AI & 3 \\
\hline \multicolumn{7}{|c|}{ B. byssoidea } \\
\hline $\mathrm{BB} 1^{\mathrm{j}}$ & MUCL 94 & U.S. & Bulb of Allium cepa & $\mathrm{ns}$ & B & 2 \\
\hline BB2 & MUCL 283 & U.S. & Bulb of Allium cepa & ns & AII & 2 \\
\hline BB3 & MUCL 3108 & Japan & Leaf of Allium cepa & ns & $\mathrm{S}$ & 2 \\
\hline BB4 & MUCL 3844 & Netherlands & Allium сера & ns & $\mathrm{S}$ & 2 \\
\hline BB5 & MUCL 9113 & Netherlands & Allium сера & ns & B & 2 \\
\hline BB6 & $B 3730^{f}$ & UK & Allium porrum & $11.8 \times 7.0$ & B & 2 \\
\hline BB7 & MUCL 30498 & - & - & ns & $\mathrm{S}$ & 2 \\
\hline \multicolumn{7}{|l|}{ B. cinerea } \\
\hline $\mathrm{BC} 1$ & $B C 1^{d}$ & Denmark & Leaf of Allium cepa & $11.4 \times 7.7$ & $\mathrm{C}$ & 2 \\
\hline $\mathrm{BC} 3$ & MUCL 3107 & U.S. & Leaf of Allium cepa & $10.4 \times 7.9$ & $\mathrm{C}$ & 2 \\
\hline $\mathrm{BC} 4$ & MUCL 3647 & Kenya & Coffea arabica & ns & $\mathrm{C}$ & 2 \\
\hline BC5 & MUCL 9115 & Netherlands & Leaf of Allium cepa & ns & $\mathrm{C}$ & 2 \\
\hline BC6 & MUCL 10117 & Israel & Bulb of Allium cepa & $\mathrm{ns}$ & $\mathrm{C}$ & 2 \\
\hline $\mathrm{BC} 7$ & MUCL 21596 & Netherlands & Leaf of Allium cepa & ns & $\mathrm{C}$ & 2 \\
\hline $\mathrm{BC} 8$ & $61-34^{\mathrm{g}}$ & U.S. & - & ns & $\mathrm{C}$ & 2 \\
\hline \multicolumn{7}{|c|}{ B. squamosa } \\
\hline BS2 & MUCL 3821 & Belgium & Leaf of Allium cepa & ns & $\mathrm{S}$ & 2 \\
\hline BS3 & MUCL 3848 & Netherlands & Allium сера & ns & $\mathrm{C}$ & 2 \\
\hline BS6 & MUCL 28710 & U.S. & Leaf of Allium cepa & ns & $\mathrm{S}$ & 2 \\
\hline BS7 & $\mathrm{B} 3808^{\mathrm{f}}$ & UK & Allium cepa & ns & $\mathrm{S}$ & 2 \\
\hline BS8 & B3834f & UK & Allium cepa & ns & $\mathrm{S}$ & 2 \\
\hline BS9 & MD-16 & U.S. & - & ns & $\mathrm{S}$ & 2 \\
\hline BS10 & $64 \mathrm{~A}^{\mathrm{g}}$ & U.S. & - & ns & $\mathrm{S}$ & 2 \\
\hline $\mathrm{BS} 11^{\mathrm{j}}$ & MUCL 1107 & U.S. & Bulb of Allium cepa & ns & $\mathrm{S}$ & 2 \\
\hline
\end{tabular}

a Average length $\times$ width of 100 conidia; and $\mathrm{ns}=$ nonsporulating in culture.

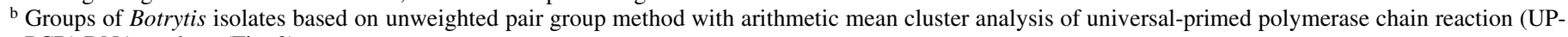
PCR) DNA markers (Fig. 2).

c Number of fragments after Sph1 digestion of internal transcribed spacer (ITS) ITS1 to ITS4 amplification product (Fig. 1).

d Provided by the Danish Institute of Agricultural Sciences, Research Center, Denmark.

e Provided by the Belgium Coordinated Collection of Microorganisms, Louvain-la-Neuve.

f Provided by S. R. Kenny, HRI, Wellesbourne, Warwick, UK (8).

g Provided by J. W. Lorbeer, Cornell University, Ithaca, NY.

${ }^{\mathrm{h}}$ Missing information.

i Provided by Centraalbureau voor Schimmelcultures, the Netherlands.

j Culture of type specimen. 
method of Möller et al. (16). DNA was dissolved in $50 \mu \mathrm{l}$ of TrisEDTA (TE) buffer (10 mM Tris-HCl, $1 \mathrm{mM}$ EDTA, pH 8.0) and stored at $-20^{\circ} \mathrm{C}$ until use. DNA concentration, estimated on agarose gels, ranged from 0.1 to $1 \mathrm{mg} / \mu \mathrm{l}$. DNA samples were diluted 10-fold for use in internal transcribed spacer (ITS) and UP-PCR analysis.

ITS restriction analysis. PCR amplification of the ITS rDNA region (Fig. 1) was performed in a final reaction volume of $20 \mu \mathrm{l}$. The following, with the final concentration indicated, were added: $2.5 \mathrm{mM} \mathrm{MgCl} 2,0.25 \mathrm{mM}$ each deoxyribonucleotide triphosphates (dNTP), dATP, dGTP, dCTP, and dTTP, 1 unit of Taq DNA polymerase (Promega, Madison, WI), $50 \mathrm{mM} \mathrm{KCl}, 10 \mathrm{mM}$ Tris- $\mathrm{HCl}$ at $\mathrm{pH} 9.0,0.1 \%$ Triton $\mathrm{X}-100,0.5 \mathrm{pmol}$ of each primer ITS1 and primer ITS4 (Table 2), and 10 to $100 \mathrm{ng}$ of fungal DNA were used. A programmable controller (PTC ${ }^{\mathrm{TM}}-100$; MJ Research Inc., Watertown, MA) was used with the following program: $94^{\circ} \mathrm{C}$ ( $3 \mathrm{~min}), 1$ cycle, $92^{\circ} \mathrm{C}(30 \mathrm{~s}), 53^{\circ} \mathrm{C}(30 \mathrm{~s}), 72^{\circ} \mathrm{C}$ (30 s), 29 cycles, $72^{\circ} \mathrm{C}$ (3 $\left.\mathrm{min}\right), 1$ cycle. PCR product $(3 \mu \mathrm{l})$ was separated on $1.5 \%$ agarose (Sigma Chemical, St. Louis) gels in $1 \times$ Tris-acetateEDTA (40 mM Tris-acetate, $1 \mathrm{mM}$ EDTA, $\mathrm{pH}$ 8.0), stained with ethidium bromide, visualized under UV light, and inspected for presence of more than one DNA band. Ten microliters of PCR product was precipitated by adding $1 \mu \mathrm{l}$ of $3 \mathrm{M} \mathrm{NaOAc}(\mathrm{pH} 4.8)$ and $25 \mu \mathrm{l}$ of $96 \% \mathrm{EtOH}$, and placing the mixture on ice for $10 \mathrm{~min}$. Precipitation mix was centrifuged for $20 \mathrm{~min}(14,000 \mathrm{rpm}$, $\left.4^{\circ} \mathrm{C}\right)$. The pellet was washed with $500 \mu \mathrm{l}$ of $70 \% \mathrm{EtOH}$ and resuspended in $20 \mu \mathrm{l}$ of TE (10 mM Tris-HCl, pH 8.0, $1 \mathrm{mM}$ EDTA). DNA $(1 \mu \mathrm{l})$ was restriction digested with Sph1 (New England Biolabs Inc., Beverly, MA) according to the manufacturer's recommendation and, after digestion, separated on a $1.5 \%$ agarose gel, stained with ethidium bromide, and visualized under UV light.

UP-PCR. In a preliminary experiment, eight primers were screened for use in the UP-PCR analysis and four primers were selected for the present study (Table 2). The DNA used for ITS amplification was also used for UP-PCR. The following, with the final concentration indicated, were added: $2.5 \mathrm{mM} \mathrm{MgCl}_{2}$, $0.35 \mathrm{mM}$ each dNTP, dATP, dGTP, dCTP, and dTTP, 1.2 units of DNA polymerase (DyNAzyme II; Finnzymes, Espoo, Fin), $50 \mathrm{mM} \mathrm{KCl}, 10 \mathrm{mM}$ Tris- $\mathrm{HCl}, \mathrm{pH} 9.0,0.1 \%$ Triton $\mathrm{X}-100$, 0.5 pmol of primer (Table 2), and 10 to $100 \mathrm{ng}$ of fungal DNA were used. A programmable controller was used with the following program: $94^{\circ} \mathrm{C}(3 \mathrm{~min}), 1$ cycle, $92^{\circ} \mathrm{C}(50 \mathrm{~s}), 52^{\circ} \mathrm{C}$ $(1 \mathrm{~min}, 10 \mathrm{~s}), 69^{\circ} \mathrm{C}(1 \mathrm{~min}), 29$ cycles, $69^{\circ} \mathrm{C}(3 \mathrm{~min}), 1$ cycle. PCR reactions were performed in a total volume of $20 \mu \mathrm{l}$. The PCR products were separated on 1.5\% agarose gels (as described previously). Presence and absence of DNA fragments were scored as 1 or 0 , respectively (Table 3). UP-PCR amplification was performed at least twice to confirm pattern of DNA fragments.

Data analysis. Variation among spore measurements for $B$. aclada subgroups AI and AII was evaluated by Hotelling's $T^{2}$ test (two-sample multivariate analysis of variance [Proc MANOVA], version 6.12, SAS Institute, Cary, NC) where conidia width and length are included in the same analysis. The two groups were treated as fixed variables (AI and AII), based on the UP-PCR data.

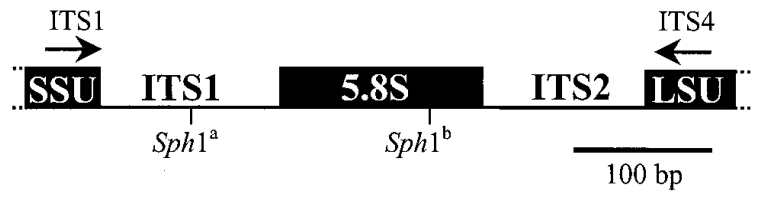

Fig. 1. Schematic diagram of the nuclear ribosomal DNA gene cluster consisting of the small subunit (SSU), 5.8S, the large subunit (LSU), and the two internal transcribed spacers (ITS1 and ITS2) based on White et al. (28). $S p h 1^{\text {b }}$ restriction site found in the ITS1 to ITS4 amplification product for all Botrytis spp. (Table 1). Sph $1^{\text {a }}$ restriction site unique for B. aclada subgroup AI. Primer sequences are shown in Table 2.
A distance-matrix $\left(1-S_{j}\right)$ of pairwise comparisons of the UP-PCR markers was constructed from Jaccard similarity coefficients $\left(S_{j}\right)$, where $S_{j}=\Sigma_{m n}(1,1) /\left[\Sigma_{m n}(0,1)+\Sigma_{m n}(1,0)+\Sigma_{m n}(1,1)\right]$; and 1 indicates presence of a band, 0 indicates absence, and $m$ and $n$ indicate the two isolates in comparison. All negative matches $(0,0)$ are excluded from the coefficient. A cluster analysis of all isolates was performed using the unweighted pair group method with arithmetic mean (UPGMA) algorithm in the program NEIGHBOR from the PHYLIP program package (J. Felsenstein, version 3.5c, Phylogenetic inference package, Department of Genetics, University of Washington, Seattle). In the UPGMA analysis, PHYLIP generates a tree file, containing information of the ordering of isolates and branch lengths. Using this tree file, a phenogram was visualized using the program TREEVIEW (23). There was made no corrections or change of ordering in this tree. Statistical support for the branches in the phenogram was tested by bootstrap analysis (4). One thousand random reassembled (with replacement) data sets were made from the original data set using the program DNAsim (N. Holst, unpublished data). These 1,000 data sets were used for generating 1,000 trees using the UPGMA algorithm in the program NEIGHBOR, and a consensus tree was generated with the program CONSENCE in the PHYLIP program package. Gene diversity $(H)(19)$ was calculated for each UP-PCR cluster, where $H=\Sigma\left(1-\Sigma x_{k}^{2}\right) / n$, and $x$ is the allele frequency of the $k$ th UP-PCR allele, and $n$ is the number of UP-PCR loci. Two alleles per UP-PCR locus were considered a null allele and a positive allele, represented by the absence or the presence of a band, respectively. Nei's coefficient of genetic differentiation $\left(G_{S T}\right)(19)$ was calculated for all pair-wise combination of the two subgroups of $B$. aclada (AI and AII) and B. byssoidea (B), where $G_{S T}=\left(H_{T}-H_{S}\right) / H_{T}$. The total gene diversity $\left(H_{T}\right)$ over all loci was calculated as $H_{T}=\Sigma\left(1-\Sigma x_{k}^{2}\right) / n$, where $x$ is the allele frequency of the $k$ th UP-PCR allele in the total population, and $n$ is the number of UP-PCR loci. The subpopulation gene diversity $\left(H_{S}\right)$ over all loci was calculated as $H_{S}=\Sigma\left(1-\Sigma x_{i k}{ }^{2}\right) / m n$, where $x$ is the allele frequency of the $k$ th UP-PCR allele in the $i$ th subpopulation, $m$ is the number of subgroups, and $n$ is the number of UP-PCR

TABLE 2. Nucleotide sequences of primers in this study

\begin{tabular}{llc}
\hline Primer $^{\mathrm{a}}$ & Nucleotide sequence 5 $^{\prime} \rightarrow 3^{\prime}$ & Reference \\
\hline ITS1 & TCCGTAGGTGAACCTGCGG & 28 \\
ITS4 & TCCTCCGCTTATTGATATGC & 28 \\
L21 & GGATCCGAGGGTGGCGGTTCT & 18 \\
AS4 & TGTGGGCGCTCGACAC & 10 \\
AS15inv & CATTGCTGGCGAATCGG & 11 \\
$3-2$ & TAAGGGCGGTGCCAGT & 3 \\
\hline
\end{tabular}

a ITS = internal transcribed spacer.

TABLE 3. Universally primed polymerase chain reaction (UP-PCR) genotypes of group AI, AII, and B

\begin{tabular}{lcr}
\hline Group $^{\mathrm{a}}$ & UP-PCR genotype $^{\mathrm{b}}$ & $N^{\mathrm{c}}$ \\
\hline AI-1 & 100101110000110001101010110101011 & 16 \\
AI-2 & 100101110000110001101010110111011 & 15 \\
AII-1 & 111111111100110111101111111101111 & 4 \\
AII-2 & 111111111110110111111111111101111 & 3 \\
AII-3 & 111111111110110111101111111101111 & 4 \\
AII-4 & 101101111110110111101111111101111 & 6 \\
AII-5 & 011111111010110011101111111101111 & 7 \\
AII-6 & 111111111110100111111111111101111 & 4 \\
B-1 & 011110011011001110110111011100101 & 12 \\
\hline
\end{tabular}

${ }^{a}$ AI-1 (BA1, BA2, BA3, BA8, BA9, BA13, BA17, BA19, BA21, BA22, BA28, BA29, and BA30); AI-2 (BA18); AII-1 (BA4); AII-2 (BA5, BA7, BA11, BA14, and BA23); AII-3 (BA6, BA10, BA12, BA16, BA24, BA26, and BA27); AII-4 (BA20); AII-5 (BA25); AII-6 (BB2); and B (BB1, BB5, and BB6).

${ }^{\mathrm{b}}$ Multilocus genotypes: 1 and 0 represent positive and null alleles, respectively, at 33 UP-PCR loci.

Number of null alleles. 
loci. A likelihood ratio chi-square test $\left(G^{2}\right)$ was performed with the null hypothesis of no difference in UP-PCR allele frequencies in the two subgroups tested $(1,24)$.

\section{RESULTS}

UP-PCR and cluster analysis. The four selected primers generated 82 reproducible bands from the 51 Botrytis isolates analyzed, collected as members of the four Botrytis spp. Each primer generated between 5 to 10 strong, reproducible bands for each of the five Botrytis groups. The isolates were clustered by UPGMA based on the matrix of Jaccard similarities and the consensus phenogram (Fig. 2) of the UP-PCR data, shows five strong clusters among the four Botrytis spp.: B (B. byssoidea), C (B. cinerea), S (B. squamosa), and AI and AII for the two observed subgroups of the B. aclada isolates. The bootstrap values calculated for statistical support of the UP-PCR groups, AI, AII, $\mathrm{B}, \mathrm{C}$, and $\mathrm{S}$, were all higher than $94 \%$, giving strong support for the individual groups. Support for the B:AI:AII branch and the C:S branch was also high (93\%), indicating a close relationship between $B$. aclada and B. byssoidea. The branch connecting AI and AII was supported by a bootstrap value of $54 \%$, which gives no support for the two $B$. aclada subgroups clustering separately from $B$. byssoidea. This means that the three groups, AI, AII, and $\mathrm{B}$, were very strongly supported, but the relationship between them remains unresolved by this analysis.

Subdivision of $\boldsymbol{B}$. aclada. As discussed previously, the UPGMA cluster analysis showed a clear subdivision of the $B$. aclada isolates into two subgroups (Fig. 2), and this subdivision was supported by restriction analysis of the ITS rDNA region (Table 1). SphI restriction analysis of the ITS rDNA region (Fig. 1) showed that all AII isolates contained two fragments (band size of approximately 220 and $320 \mathrm{bp}$, Table 1) and all group AI isolates contained three fragments (band size of approximately 120, 200, and $220 \mathrm{bp}$ ). The MANOVA showed the spore sizes (length $\pm \mathrm{SE} \times$ width $\pm \mathrm{SE}$ ) of the two subgroups of B. aclada, AI $(9.5 \pm 0.3 \times 5.1 \pm 0.1)$ and AII $(11.0 \pm 0.3 \times 6.0 \pm 0.1)$, to be significantly different $\left(F_{2,24}=13.27 ; P<0.0001\right)$. Some overlap in spore size between the two groups was observed (Table 1). Most isolates of B. aclada (except for BA13 and BA14 which did not

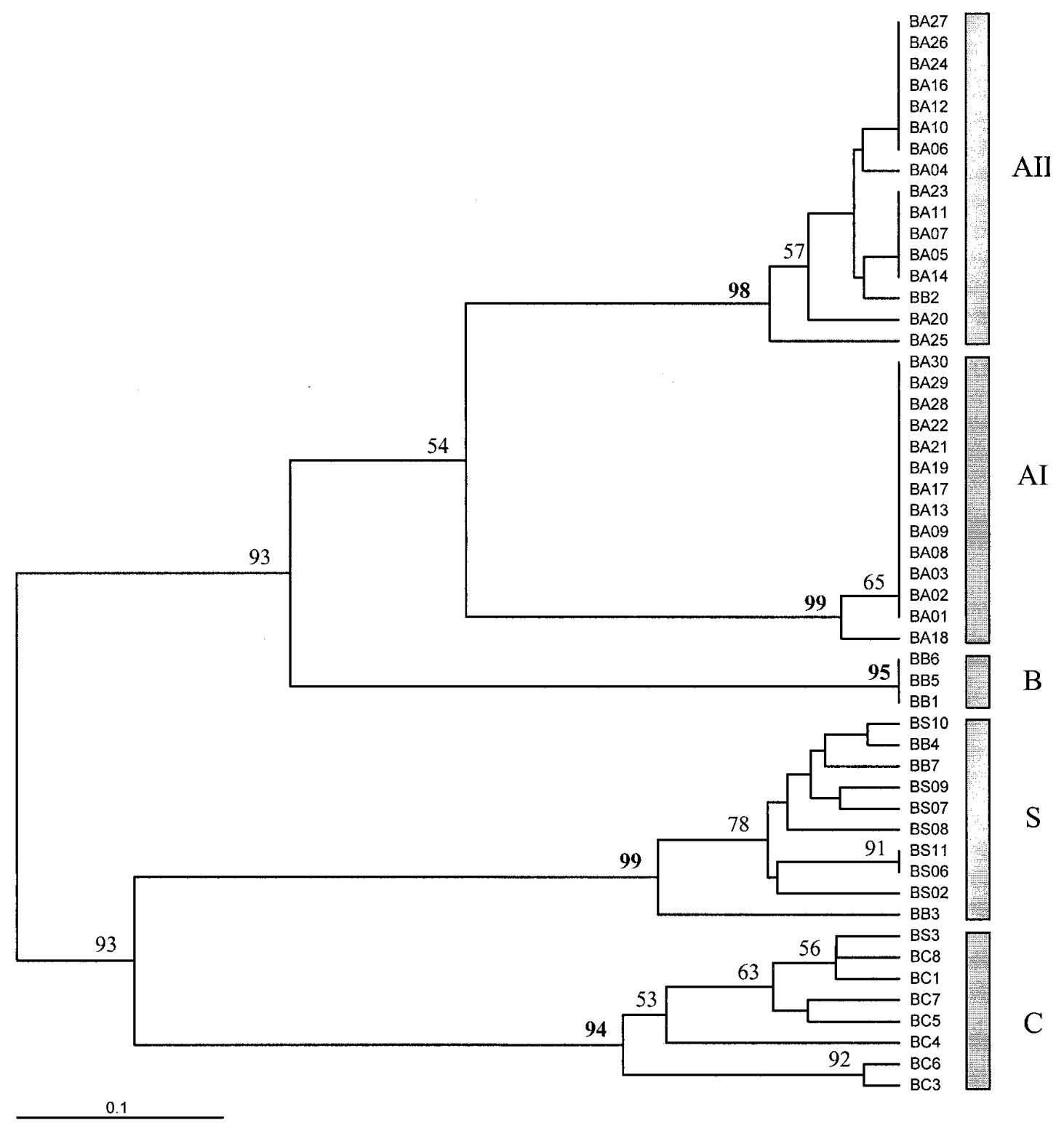

Fig. 2. Unweighted pair group method with arithmetic mean cluster analysis of Jaccard similarities among universally primed polymerase chain reaction markers scored for 51 isolates of Botrytis cinerea (C), B. squamosa (S), B. byssoidea (B), and two subgroups of B. aclada (AI and AII). Number at major branches indicates percent occurrence of the cluster to the right of the branch in 1,000 bootstrap trees generated from 82 bands sampled with replacement. Bar indicates genetic distance. Only branches occurring in 50\% or more of the bootstrap trees (i.e., majority-rule consensus tree) are labeled. 
sporulate) easily produced abundant conidia on OEA with characteristic flat and sparse production of mycelium, leaving no doubt about identity.

Genetic variability within UP-PCR groups. All eight $C$ isolates and nearly all $10 \mathrm{~S}$ isolates (except BS11 and BS6 which were identical) had unique UP-PCR genotypes (data not shown), and the gene diversities $(H)$ among the isolates were 0.143 and 0.102 , respectively. For the B. aclada and B. byssoidea isolates, 33 positive UP-PCR alleles were identified (Table 3). Of $30 \mathrm{~B}$. aclada isolates, obtained from all over the world, 14 were AI types. These isolates were almost identical, and only one isolate (BA18) differed from the others, by a single UP-PCR band. The gene diversity among the AI isolates was 0.007 , and the similarity coefficient between the two AI genotypes was 0.94 (Table 4). Subgroup AII showed more variation, and six UP-PCR genotypes were observed among the 16 isolates in the present study. However, similarity coefficients between the AII genotypes ranged from 0.83 to 1.00 (Table 4), and the gene diversity among isolates was 0.043 , indicating low genetic variation in this subgroup as well. The three $B$. byssoidea isolates designated to group B were identical (Table 3).

Genetic differentiation of intraspecies groups. The UPGMA analysis showed that AI, AII, and B were clustered strongly, but it also showed that differentiation of the AI:AII cluster from the B cluster was not supported. This indicates a very close relationship between $B$. aclada and B. byssoidea. In all pair-wise comparisons there was a highly significant genetic differentiation between the subgroups (Table 5). AI:AII genotypes and AII:B genotypes have almost identical similarity coefficients, respectively, between 0.52 to 0.61 and 0.50 to 0.61 . However, $\mathrm{AI}$ and $\mathrm{B}$ genotypes have similarity coefficients between 0.22 to 0.23 (Table 4 ), and this is comparable to the similarity coefficient between $\mathrm{C}: \mathrm{S}$ genotypes of 0.22 to 0.28 (data not shown). Seven UP-PCR alleles were present in all AI, AII, and B isolates; 10 alleles were exclusively associated with AI:AII and 12 with AII:B, but no UP-PCR alleles were exclusive to AI:B (Table 3). These data indicate that AII is genetically intermediate between AI and B.

Isolate identity. Identity of some of the isolates from the culture collections was not supported by our UP-PCR analysis. We have, nevertheless, chosen to keep our original designations of the isolates (i.e., as the species received from culture collections) because we do not have morphological evidence for the identity of the $B$. byssoidea and B. squamosa isolates. Of the seven B. bys- soidea isolates obtained from culture collections, only two isolates (BB5 and BB6) grouped strongly with a culture of the B. byssoidea type specimen (BB1) (Table 1). Isolates BB2, BB3, BB4, and $\mathrm{BB} 7$ were, based on UP-PCR fingerprint analysis, grouped with B. aclada subgroup AII (BB2) or B. squamosa (BB3, BB4, and $\mathrm{BB} 7)$. The history of isolate $\mathrm{BB} 7$ shows that MUCL received it as B. squamosa, but that it was reassigned to B. byssoidea. Our analysis indicates that the reassignment was probably incorrect and that $\mathrm{BB} 7$ is a $B$. squamosa isolate. Isolate BS3 was received as a $B$. squamosa, but the UP-PCR DNA fingerprint showed a closer relation to the $B$. cinerea group (Table 1 ). Similar to $B$. byssoidea, $B$. squamosa seldom sporulate on artificial media, and lack of sporulation makes is very difficult to make a correct diagnosis of the isolate by traditional methods.

\section{DISCUSSION}

The UPGMA and bootstrap analysis of UP-PCR fingerprints of the Botrytis isolates gave strong support for the $B$. cinerea group (C), the B. squamosa group (S), and the B. byssoidea group (B). $B$. aclada isolates clustered in two genetically distinct subgroups, AI and AII. Spore size measurements and ITS restriction analysis supported this subdivision of $B$. aclada isolates. Previous work has shown that B. aclada consisted of two subgroups $(5,26)$, but this is the first investigation, to our knowledge, that clearly demonstrates a substantial genetic difference between the two $B$. aclada subgroups. Differentiation between the two subgroups of B. aclada cannot be made solely on the basis of spore size, however restriction fragment length polymorphism analysis of the ITS rDNA region with $S p h$ I can differentiate the two subgroups of $B$. aclada. The ITS rDNA region had been sequenced for a few isolates of $B$. aclada, B. byssoidea, B. squamosa, and B. cinerea in a previous study (21). This sequence information revealed that restriction digest with the enzyme $S p h \mathrm{I}$ was able to cut $B$. aclada (AII), B. byssoidea, B. squamosa, and $B$. cinerea once, whereas $B$. aclada (AI) would be cut twice. This was true for all isolates investigated. Shirane at al. (26) have shown that cells of the largespored subgroup of $B$. aclada contain 32 chromosomes, whereas cells of the small-spored subgroup contain 16 chromosomes. In the present work, the large-spored B. aclada subgroup is called AII and the small-spored subgroup is called AI. Shirane et al. (26) suggested that the 32 chromosomal B. aclada subgroup is an autodiploid of the 16 chromosomal B. aclada subgroup. If this hy-

TABLE 4. Jaccard similarity coefficients between universally primed polymerase chain reaction (UP-PCR) genotypes

\begin{tabular}{|c|c|c|c|c|c|c|c|c|}
\hline UP-PCR genotype & AI-2 & AII-1 & AII-2 & AII-3 & AII-4 & AII-5 & AII-6 & B \\
\hline AI-1 & 0.94 & 0.61 & 0.57 & 0.59 & 0.63 & 0.59 & 0.53 & 0.23 \\
\hline AI-2 & $\ldots$ & 0.59 & 0.55 & 0.57 & 0.61 & 0.57 & 0.52 & 0.22 \\
\hline AII-1 & $\ldots$ & $\ldots$ & 0.93 & 0.97 & 0.90 & 0.86 & 0.90 & 0.53 \\
\hline AII-2 & $\ldots$ & $\ldots$ & $\ldots$ & 0.97 & 0.90 & 0.87 & 0.97 & 0.59 \\
\hline AII-3 & $\ldots$ & $\ldots$ & $\ldots$ & $\ldots$ & 0.93 & 0.90 & 0.93 & 0.56 \\
\hline AII-4 & $\ldots$ & $\ldots$ & $\ldots$ & $\ldots$ & $\ldots$ & 0.93 & 0.87 & 0.50 \\
\hline AII-5 & $\ldots$ & $\ldots$ & $\ldots$ & $\ldots$ & $\ldots$ & $\ldots$ & 0.83 & 0.57 \\
\hline AII-6 & $\ldots$ & $\ldots$ & $\ldots$ & $\ldots$ & $\ldots$ & $\ldots$ & $\ldots$ & 0.61 \\
\hline
\end{tabular}

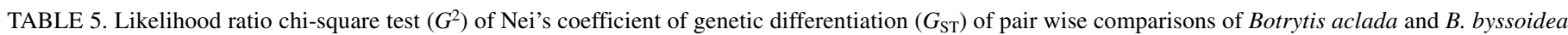
subgroups AI, AII, and B

\begin{tabular}{|c|c|c|c|c|c|c|}
\hline UP-PCR groups ${ }^{a}$ & $H_{S}^{\mathrm{b}}$ & $H_{T}{ }^{\mathrm{c}}$ & $G_{S T}^{\mathrm{d}}$ & $\mathrm{df}$ & $G^{2 \mathrm{e}}$ & $P^{\mathrm{f}}$ \\
\hline AI-AII & 0.023 & 0.198 & 0.884 & 33 & 473 & $<0.001$ \\
\hline AI-B & 0.003 & 0.366 & 0.992 & 33 & 381 & $<0.001$ \\
\hline AII-B & 0.024 & 0.222 & 0.892 & 33 & 209 & $<0.001$ \\
\hline
\end{tabular}

a The 33 universally primed polymerase chain reaction (UP-PCR) loci used for calculation shown in Table 3.

${ }^{\mathrm{b}}$ Genetic diversity within subpopulations.

c Total genetic diversity over all subpopulations.

d Nei's genetic differentiation between subpopulations.

e Likelihood ratio chi-square test. Null hypothesis of no difference in allele frequencies among subpopulations over the 33 UP-PCR loci.

f $P=$ probability for $G^{2}$. 
pothesis were correct then it would be expected that the genetic differentiation between the two subgroups would be small because of identity among the copies of the genome in the 32 chromosomal subgroup. Our data do not support this conclusion, because analysis of genetic differentiation of the subgroups AI and AII shows that they are very different; $B$. aclada subgroups AI and AII could be two separate species.

The $B$. byssoidea isolates, although identical, were supported by a bootstrap value of only $95 \%$. This is a consequence of the bootstrap method, where random data sets are generated with replacement resulting in new data sets in which some characters are represented more than once and other characters are excluded. In approximately $5 \%$ of these data sets, characters separating B. byssoidea from other isolates were excluded.

Many researchers have speculated that $B$. aclada and $B$. byssoidea are conspecific, mainly because they have overlapping spore size and because they cause similar symptoms of disease (onion neck rot). Our analysis of genetic differentiation between B. byssoidea isolates (B) and B. aclada (AI and AII) isolates clearly shows that the three subgroups are very different, and most likely are not conspecific. The pair-wise similarity coefficients between AI, AII, and B isolates show that AII is equally similar to both $\mathrm{AI}$ and $\mathrm{B}$, but $\mathrm{AI}$ and $\mathrm{B}$ are as different from each other as $B$. squamosa isolates (S) are from $B$. cinerea isolates (C). This might indicate that AII is a hybrid species between $\mathrm{AI}$ and B. This hypothesis fits with the results of Shirane et al. (26), because AII could have become polyploid (32 chromosomes) by fusion of AI (16 chromosomes) and B (16 chromosomes). Another indication is that AII isolates consisted exclusively of UP-PCR bands that were present in either AI or B. Similar DNA band patterns have recently been reported in analysis of plant and oomycete hybrids using PCR-mediated DNA markers $(12,25)$. Resolution of the hybridization hypothesis is inferred from sequences of specific genes, in which ambiguous sites in the AII sequences were shown at positions in the sequence where $\mathrm{AI}$ and $\mathrm{B}$ have different nucleotides (20). Although we found no evidence for pathogenic specialization between the two B. aclada groups (data not shown), screening of new germ plasm and evaluation of new management strategies would be strengthened by mixing a diverse sample of the pathogens from both $B$. aclada groups and B. byssoidea.

Great variation was observed in $B$. cinerea isolates and $B$. squamosa isolates. All $B$. cinerea isolates and nearly all $B$. squamosa isolates had unique genotypes. Both species reproduce sexually in nature, and thus have the potential for generating high levels of genetic variation within populations, as observed. No perfect state has been identified for $B$. aclada, and the almost complete lack of variation at DNA level of B. aclada subgroup AI can be taken as strong support for clonality of this subgroup. The variation in B. aclada subgroup AII was somewhat greater; six UP-PCR genotypes were identified among 16 isolates. The samples of AI and AII isolates originated from many different regions in Europe and Northern America and were collected over nearly a century (data not shown). This supports both the separation of the two subgroups and the relative invariability among isolates in each of the B. aclada subgroups. B. byssoidea was only represented by three isolates (including a culture of the type specimen), and thus our finding of no variation within this group must be taken cautiously. The perfect state of B. byssoidea, Botryotinia allii, has only been observed in Japan, where it causes leaf blight, whereas $B$. byssoidea causes disease to onion bulbs (5). The type specimen of $B$. byssoidea was collected in the United States in 1925 and the two other authentic B. byssoidea isolates in this work were collected in the United Kingdom in 1984. It may be that Botryotinia allii mainly reproduces asexually in Europe and in the United States, or it could be that B. byssoidea and Botryotinia allii represent two separate species. Resolution of this question is beyond the scope of the present study.
B. byssoidea is traditionally identified on artificial media by sparse or absent sporulation, and by production of white fluffy mycelium and lack of sclerotial production (5). Five of six B. byssoidea isolates obtained from culture collections were incorrectly identified, according to our analysis. This illustrates the inadequacy of traditional morphological methods when nonsporulating isolates are to be identified. More certain diagnoses of nonsporulating Botrytis isolates can be obtained with DNA fingerprinting methods.

\section{ACKNOWLEDGMENTS}

This work was financed by the Danish Ministry of Agriculture and Fisheries, Program; Biologisk og mikrobiologisk bekæmpelse af skadevoldere (1996 to 2000); and the Danish Institute of Agricultural Sciences, Flakkebjerg, Denmark. We thank S. R. Kenny and J. W. Lorbeer for providing us with some of the isolates, $\mathrm{M}$. Lübeck for help establishing the UP-PCR method, and T. L. Peever for comments on the analysis of genetic differentiation.

\section{LITERATURE CITED}

1. Brown, J. K. M. 1996. The choice of molecular marker methods for population genetic studies of plant pathogens. New Phytol. 133:183-195.

2. Bulat, S. A., Lübeck, M., Mironenko, N. V., Jensen, D. F., and Lübeck, P. S. 1998. UP-PCR analysis and ITS ribotyping of strains of Trichoderma and Gliocladium. Mycol. Res. 102:933-943.

3. Bulat, S. A., Mironenko, N. V., Lapteva, M. N., and Strelchenko, P. P. 1994. Polymerase chain reaction with universal primers (UP-PCR) and its application to plant genome analysis. Pages 113-129 in: Conservation of Plant Genes II: Utilization of Ancient and Modern DNA. R. P. Adams, J. S. Miller, E. M. Goldenberg, and J. E. Adams, eds. Missouri Botanical Garden, St. Louis.

4. Felsenstein, J. 1985. Confidence limits on phylogenies: An approach using the bootstrap. Evolution 39:783-791.

5. Hennebert, G. L. 1963. Les Botrytis des Allium. Meded. Landbouwhogesch. Opzoekingsstn. Staat Gent 28:851-876.

6. Hennebert, G. L. 1973. Botrytis and Botrytis-like genera. Persoonia 7:183-204.

7. Lacy, M. L., and Lorbeer, J. W. 1995. Botrytis neck rot. Pages 18-19 in: Compendium of Onion and Garlic Diseases. H. F. Schwartz and S. K. Mohan, eds. The American Phytopathological Society, St. Paul, MN.

8. Linfield, C. A., Kenny, S. R., and Lyons, N. F. 1995. A serological test for detecting Botrytis allii, the causal agent of neck rot of onion bulbs. Ann. Appl. Biol. 126:259-268.

9. Lorbeer, J. W. 1980. Variation in Botrytis and Botryotinia. Pages 19-39 in: The Biology of Botrytis. J. R. Coley-Smith, K. Verhoeff, and W. R. Jarvis, eds. Academic Press, London.

10. Lübeck, M. 1997. Marker genes and PCR based approaches as tools for monitoring fungi in soil - with emphasis on UP-PCR and fungi from the genera Trichoderma and Gliocladium. Ph.D. thesis. The Royal Veterinary and Agricultural University, Copenhagen, Denmark.

11. Lübeck, P. S., Alekhina, I. A., Lübeck, M., and Bulat, S. A. 1998. UPPCR genotyping and rDNA analysis of Ascochyta pisi Lib. isolates. J. Phytopathol. 146:51-55.

12. Man in't Veld, W. A., Veenbaas-Rijks, W. J., Ilieva, E., de Cock, A. W. A. M., Bonants, P. J. M., and Pieters, R. 1998. Natural hybrids of Phytophthora nicotianae and Phytophthora cactorum demonstrated by isozyme analysis and random amplified polymorphic DNA. Phytopathology 88:922-929.

13. Maude, R. B. 1988. Ascomycetes V: Botrytis allii. Pages 431-432 in: European Handbook of Plant Diseases. I. M. Smith, J. Dunez, R. A. Lelliott, D. H. Phillips, and S. A. Archer, eds. Blackwell Scientific Publications, Oxford.

14. Maude, R. B., and Presly, A. H. 1977. Neck rot (Botrytis allii) of bulb onions. I. Seed-borne infection and its relationship to the disease in the onion crop. Ann. Appl. Biol. 86:163-180.

15. Maude, R. B., and Presly, A. H. 1977. Neck rot (Botrytis allii) of bulb onions. II. Seed-borne infection in relationship to disease in store and the effect of seed treatment. Ann. Appl. Biol. 86:181-188.

16. Möller, E. M., Bahnweg, G., Sandermann, H., and Geiger, H. H. 1992. A simple and efficient protocol for isolation of high molecular weight DNA from filamentous fungi, fruit bodies, and infected plant tissues. Nucleic Acids Res. 20:6115-6116.

17. Morgan, D. J. 1971. Numerical taxonomic studies of the genus Botrytis II. Other Botrytis taxa. Trans. Br. Mycol. Soc. 56:327-335. 
18. Naumov, G. I., Naumov, E. S., Kondratieva, V. I., Bulat, S. A., Mironenko, N. V., Mendonca-Hagler, L. C., and Hagler, A. N. 1997. Genetic and molecular delineation of three sibling species in the Hansenula polymorpha complex. Syst. Appl. Microbiol. 20:50-56.

19. Nei, M. 1973. Analysis of gene diversity in subdivided populations. Proc. Natl. Acad. Sci. 70:3321-3323.

20. Nielsen, K. 2000. Molecular characterisation and biological control of grey mould (Botrytis spp.) in onion. Ph.D. thesis. The Royal Veterinary and Agricultural University, Copenhagen, Denmark.

21. Nielsen, K., Justesen, A. F., and Yohalem, D. S. 1999. PCR based detection of latent infections of Botrytis aclada Fres. in onion bulbs. Petria 9:105-108.

22. Owen, J. H., Walker, J. C., and Stahmann, M. A. 1950. Variability in onion neck rot fungi. Phytopathology 40:749-768.

23. Page, R. D. M. 1996. TREEVIEW: An application to display phylogenetic tree on personal computers. Comp. Appl. Biosci. 12:357-358.

24. Peever, T. L., Canihos, Y., Olsen, L., Ibañez, A., Liu, Y.-C., and Timmer, L. W. 1999. Population genetic structure and host specificity of Alter- naria spp. causing brown spot of Minneola tangelo and rough lemon in Florida. Phytopathology 89:851-860.

25. Pemberton, J. M., Slate, J., Bancroft, D. R., and Barrett, J. A. 1995. Nonamplifying alleles at microsatelite loci: A caution for parentage and population studies. Mol. Ecol. 4:249-252.

26. Shirane, N., Masuko, M., and Hayashi, Y. 1989. Light microscopy observation of nuclei and mitotic chromosomes of Botrytis species. Phytopathology 79:728-730.

27. Walker, J. C. 1925. Two undescribed species of Botrytis associated with the neck rot disease of onion bulbs. Phytopathology 15:708-713.

28. White, T. J., Bruns, T., Lee, S., and Taylor, J. 1990. Amplification and direct sequencing of fungal ribosomal RNA genes for phylogenetics. Pages 315-322 in: PCR Protocols, A guide to Methods and Applications. M. A. Innis, D. H. Gelfand, J. J. Sninsky, and T. J. White, eds. Academic Press, San Diego.

29. Williams, J. G. K., Kubelic, A. R., Livak, K. J., Rafalski, J. A., and Tingey, S. V. 1990. DNA polymorphisms amplified by arbitrary primers are useful as genetic markers. Nucleic Acids Res. 18:6231-6235. 